\title{
Johann Michael Haydn's Missa Sancti Hieronymi: An Unusual Eighteenth-Century Tribute to Saint Jerome
}

\author{
Jane Schatkin Hettrick ${ }^{*}$
}

On 14 September 1777, Johann Michael Haydn (younger brother of the more famous Franz Joseph Haydn), serving as court musician to the prince-archbishop of Salzburg, completed a Mass entitled Missa Sancti Hieronymi. This essay will attempt to place this Mass in the church-music context of the time and place. It will also examine the association of this work with the archbishop and the relationship between the composer and his employer. Finally, it will consider what personal purpose the composer may have had in writing this Mass.

Since the Mass bears the title "St. Jerome," it would appear that Haydn intended it to honor the name-day of his employer, Count Hieronymus Joseph Franz de Paula Colloredo, on 30 September, the feast day of St. Jerome. ${ }^{1}$ The surviving Salzburg Hof-Kalender of the following year $(1778)^{2}$ marks the saint's day and also notes 30 September as the name-day of the prince. Yet, we have no record of a performance of this Mass on that date. Instead, it was first performed on All Saints'

* Rider University (New Jersey), jhettrick@rider.edu.

1 Colloredo (1732-1812), second son of Count Rudolf Wenzel Joseph Colloredo-Melz und Wallsee, was the last reigning Prince-Archbishop of Salzburg. Educated at the Theresianum in Vienna, he also studied at the Collegium Germanicum in Rome. By 1747 named a canon at the Salzburg cathedral; in 1761, Prince-Bishop of Gurk; 14 March 1772, elected Prince-Archbishop of Salzburg. Clive, Mozart and His Circle, s.v. Colloredo; Schuler, "Fürsterzbischof Hieronymus von Colloredo," 3 .

2 No calendar from 1777 was found. 
Day, 1 November 1777, in the Salzburg cathedral under the direction of the composer.

The scoring is quite unusual. It is found in none of Haydn's other liturgical music, including his more than thirty Masses, and it is unique in the Mass repertoire of the Salzburg court. Indeed, it is unknown in the whole body of Austrian Masses of the late eighteenth century. ${ }^{3}$ The orchestra consists of a wind band: four oboes, two bassoons, and three trombones, plus organ and basso continuo. There are no strings except for the cello and bass of the continuo. Its unconventional orchestra makes this Mass difficult to classify liturgically. It lacks the trumpets and drums associated with "pallium" feasts, on which the archbishop would be the celebrant. ${ }^{4}$ Yet oboes also belonged to that type of occasion, although not necessarily in the large number featured in this Mass.

While little performed in the composer's lifetime, the Missa Sancti Hieronymi later became one of his most-cited Masses. ${ }^{5}$ It came to wider attention through words of praise in a letter of 1 November 1777, written to Wolfgang Amadeus Mozart by his father, Leopold. Leopold Mozart ${ }^{6}$ was himself a fine musician, and he could be at times a harsh critic. Therefore, his high opinion of Michael Haydn's music stands out. Calling it the "oboe mass" [Hautb:Meß] he wrote:

I came just this moment from Mass at the cathedral. It was the oboe-Mass, composed by Haydn, which he directed himself. There was also the offertory, and instead of the sonata, the words of the gradual, which the priest prayed, likewise composed. Yesterday it was rehearsed after Vespers. The prince did not preside over the service. [...] Everything pleased me extraordinarily well, with the six oboes, three contrabasses, and two bassoons. [...] The entire ceremony lasted one and a quarter hours, but to me, that was too short, for it was really excellently composed. Everything proceeded very naturally; the fugues, especially the Et vitam etc. in the Credo

3 Johann Michael Haydn, Missa Sancti Hieronymi, ed. Kircher, iv.

4 Pallium is a liturgical vestment worn by an Archbishop, representing his position as a metropolitan in communion with the Church of Rome. Stelten, Dictionary of Ecclesiastical Latin, 318.

5 Erick Arenas, personal communication.

6 Leopold Mozart (1719-1787), composer and violinist, served from 1743 as violinist in the Salzburg court ensemble, becoming vice-Kapellmeister in 1763 . He dedicated much of his life to the musical education and advancement of his son's career; his most famous work was the pedagogical treatise on the violin, Versuch einer gründlichen Violinschule, Augsburg, 1756. Clive, s.v. Mozart, Leopold. 
and the Dona nobis, then the Alleluia in the offertory were really masterfully worked out; the themes were natural and not brought to an exaggerated modulation or sudden [harmonic] shift.?

Like his father, Wolfgang Mozart held Michael Haydn in high regard, describing him in a letter to Padre Martini ${ }^{8}$ as "one of Salzburg's superlative masters of counterpoint."9 As Charles Sherman has noted, the Mozarts maintained an ongoing interest and admiration for Michael Haydn's music: Wolfgang frequently asked about Haydn's newest compositions, "borrowed them, copied them, and eventually used many of them for his own works." ${ }^{10}$ Although during his lifetime, Michael was often compared to his more-famous brother Franz Joseph, as a composer of church music he acquired a reputation as having special gifts. A tribute to Haydn at the time of his death, written by a colleague in Salzburg, reflects that opinion: "He was as excellent a composer as he was a performer; he distinguished himself particularly in composition for the church. He wrote a Mass for the King of Spain; two Masses, a Vesper, and Psalms etc., for Her Majesty the Holy Roman Empress; and Masses, Vespers, Te Deums, Sequences, Graduals, Applausus etc., for the cathedral, St. Peter's, and other places." ${ }^{\prime 1}$

In the mid-eighteenth century, Vienna and all Catholic Austria saw much controversy over the theory and practice of church music. Opinions are recorded in numerous official documents. One of these is the encyclical Annus qui, promulgated by Pope Benedict XIV in 1749. This pope finds many faults with contemporary church music. The theme of theatricality comes up again and again. "All condemn theatrical chant in churches and want a distinction made between the sacred chant of the Church and the profane chant of the theatre." "We need to fix the limits between Church chant and music and that of the theaters." ${ }^{13}$ Benedict finds support for the need to purge theatrical music from the church in earlier writings. For example, the Council

Letter to Wolfgang, 1 November 1777, in Mozart, ed. Bauer and Deutsch, 95-96. Translation mine.

8 Giovanni Battista Martini (1706-1784), was a composer, teacher of composition, collector, scholar, and historian. His pupils included W. Mozart and other leading musicians of the time.

9 Sherman, "The Masses of Johann Michael Haydn," 7.

10 Ibid.

11 Sherman and Donley Thomas, Johann Michael Haydn (1737-1806), vii.

12 Hayburn, Papal Legislation on Sacred Music, 98.

13 Ibid., 103. 
of Toledo in 1566 concluded: "It is absolutely necessary to avoid all that is theatrical in the music used for the chant of divine praises and everything that evokes profane themes of love or warrior feats dear to classic music. ${ }^{14}$ From Drexilius, he cites: "At the present day a kind of chant has crept into the temple which is new, eccentric, broken up with a swing and certainly far from religious. It is more suitable for the theatre and dance halls." ${ }^{15}$ Finally, Benedict condemns what he calls the "most inconvenient abuse," that is, "sumptuous orchestral music" in the Mass: "We cannot be silent over the most inconvenient abuse and which must not be tolerated: on certain days of the year sacred buildings are the theatre for sumptuous and resounding concerts, which in no way agree with the Sacred Mysteries which the Church, precisely on those days, proposes to the veneration of the faithful." ${ }^{16}$ The author of Annus qui foresees a slippery slope that begins with theatrical music and ends in "grave sins and scandals." To illustrate, he recounts a sixteenth-century incident in the north-Italian city of Lucca, as recorded by Pope Pius V. Here, "Recently to Our great grief, We learned that $[\ldots]$ there is the most detestable abuse of holding unheard of musical concerts in churches during Holy Week, with the assembling of selected singers and every sort of instrument. A greater crowd of young people of both sexes flows into the concerts than into Divine Ceremonies, attracted to them by a real passion, and experience has shown that they commit grievous sins and that no lesser scandals arise."17

The same scene replayed itself in Austrian churches two hundred years later, and new voices recycled the same complaints. We will see that Archbishop Colloredo, in 1782, also uses the word "abuse" to criticize orchestral music in the church. The state, which supported Catholic doctrine, also attempted to regulate the practice of church music. In the 1750 in Vienna, the imperial government issued a series of Hofreskripte intended to restrain types of music considered to be excessive or superfluous in the church. State decrees focused on the use of trumpets and timpani, which were included in many Masses

Ibid., 99 .

Ibid., 101.

16 Ibid., 104 .

17 Ibid., 105. The word "concerts" here could suggest non-sacred music. This is unlikely, however. Another description refers specifically to: "flowery musical variations with which [...] they dress up the Lamentations of the Prophet Jeremias [...] or the chant in which the prophet weeps over the destruction of Jerusalem by the Chaldeans [...] and the anguish of Our Redeemer during His Passion." Ibid., 104. 
and other liturgical music of the time. In 1754, under Empress Maria Theresia, the court issued a Hofreskript that banned the use of these instruments in church music. ${ }^{18}$

Music was indeed a prominent feature in worship in the Austrian Catholic Church around the 1770 s and 1780 s, and Salzburg shared in that practice. ${ }^{19}$ Every church had its music - by today's standards, a lot of music. Moreover, Catholic worship extended beyond Sunday Mass to include daily Mass and a significant number of Holy Days and other liturgies. Music performed at these services generally involved choir, soloists, and instruments. British music historian Charles Burney visited Vienna in 1772 and attested to the popularity of musical church services in the imperial city. "There is scarce a church or convent in Vienna which has not every morning its mass in music: that is, a great portion of the church service of the day, set in parts, and performed with voices, accompanied by at least three or four violins, a tenor and base, [sic] besides the organ." ${ }^{20}$

One outspoken critic of church music at that time was the author of a pamphlet entitled Ueber die Kirchenmusik in Wien, published in 1781. Under this neutral title, the anonymous author satirizes what he perceives as abuses in church music of the day. To this writer, just like Lucca in the sixteenth century, the church of his own time had turned into a concert hall. He sees the same downward path ending in "grave sins and scandals." He paints a vivid and damning picture: Catholic worshippers were being entertained by tunes from opera, masquerading only thinly as sacred music. He means here music culled from an opera, possibly one in the current repertoire. Despite the substitution of a sacred

Mac Intyre, The Viennese Concerted Mass of the Early Classical Period, 43. This followed a decree put out by the arch-episcopal Konsistorium of Vienna in Dec. 1753 banning trumpets and timpani in church services. This rule, however, may have applied only to intradas (fanfares played by trumpet choirs), performed at important feasts and at certain designated points in the Te Deum. See Glöggl, Kirchenmusik-Ordnung, \#16: "Vom Gebrauch der Trompeten und Pauken in der Kirche."

19 Salzburg was a member-state of the Holy Roman Empire, one of four governed by a prince-archbishop rather than a hereditary secular ruler. It functioned generally independent of the Habsburg monarchy, but was subject to influence from Vienna. It "ranked as one of the oldest and most venerable archbishoprics of the German-speaking world." Arenas, "Johann Michael Haydn and the Orchestral Solemn Mass," 128.

Burney, The Present State of Music, 226-227. 
text, people would recognize it for what it was - a theater piece minus its secular text.

One does not have to read much between the lines to learn the author's agenda here. His goal was to promote the reforms of liturgy and church music instituted by Emperor Joseph II. This Emperor, motivated by Enlightenment ideals of simplicity and his desire to reduce costs, issued in 1783 a new Gottesdienstverordnung. His "new order of worship" significantly reduced the number of services and severely limited the amount of music permitted in them. Joseph ultimately wanted to promote "Normalgesang," that is, the use of vernacular hymns sung by the congregation. His mother and co-ruler Empress Maria Theresia had in 1774 sponsored the publication of a German-language hymnal. ${ }^{21}$ Other hymnals in German followed. Thus, Michael Haydn (and his colleagues) worked in a transitional, often troubled musical and ecclesiastical environment.

Salzburg had a long history of strict Catholic orthodoxy. ${ }^{22}$ Called the "German Rome" because of its many churches, it was an important and influential archdiocese. With a distinguished musical history, it boasted some of the foremost musicians, including, in the sixteenth century, composer Heinrich Finck, organist Paul Hofhaimer, and later, of course, the Mozarts. First organized by Archbishop Wolf Dietrich, the musical establishment when Haydn served there had grown in size and quality to an ensemble befitting a princely court. ${ }^{23}$ The Salzburg cathedral calendar had a full schedule of musical liturgies: high Masses, sung offices, and extra rites, such as priestly ordinations. ${ }^{24}$ Archbishop Siegmund Christoph Schrattenbach (1753-71) maintained a splendid musical program, sparing no expense to support his musicians. However, reform was in the air, and the Salzburger Kongress (1770-77) opened the door for church reform, although it produced no lasting changes.

The chief spokesman for Emperor Joseph's reform program was Archbishop Colloredo, remembered today as the autocratic

21 Katholisches Gesangbuch auf allerhöchsten Befehl Ihrer k. k. apost. Majestät Marien Theresiens zum Druck befördert. This hymnal contains 87 texts and 48 melodies; each text has a designated melody.

The Jews were expelled in 1498 and Protestants in 1731-32. See Reformation Emigration (Salzburg, 1981).

23 According to a document compiled by Leopold Mozart, Nachricht von dem gegenwärtigen Zustande der Musik Sr. Hochfürstl. Gnaden des Erzbishoffs zu Salzburg im Jahr 1757, the ensemble consisted of ninety-nine persons. A translation of the entire document is found in Zaslaw, Mozart's Symphonies, 550-557.

24 Arenas, "Johann Michael Haydn," 135. 
employer of Mozart. Raised in Vienna and imbued with the spirit of the Enlightenment, Colloredo was never beloved by his people in Salzburg. Apparently selected by the Emperor, his election to the office of archbishop, taking numerous ballots, did not run smoothly. He governed by Enlightenment ideas, nurtured in Vienna. In 1782, five years after Haydn's Missa Sancti Hieronymi, Colloredo penned a lengthy pastoral letter to all clergymen under his aegis: Hirtenbrief auf die am 1sten Herbstm. dieses 1782ten Jahrs, nach zugelegten zwölften Jahrhundert, eintretende Jubelfeier Salzburgs. ${ }^{25}$ While this document formally sets forth his reformist principles, it is likely that changes had already begun to be implemented during the preceding years. ${ }^{26}$ Welcoming its support for his own intended reforms, Joseph II distributed it to all the dioceses in the crown lands. ${ }^{27}$

Colloredo started from a worthy goal: to return to (Catholic) Christianity basics. He intended that people should pray from the heart rather than by lip service and rote formulas. Rather, they must worship "in spirit and truth" (John 4:24). Along with this renewed focus on biblical Christianity came the more worldly purpose of the Mass as a practical teaching tool. The sermon, for example, should instruct, correct, and soothe listeners, making them into good men, citizens, and Christians. ${ }^{28}$ As historian Joseph Jungmann put it, such Enlightenment theologians: "wanted to make of divine service a human service designed for instruction and moral admonition." ${ }^{29}$ Colloredo (and similar thinkers) believed it necessary to purify worship by purging all excess to obtain these ends. This process affected the number of liturgical rites, amount of content, decoration, actions, and of course, music. Only a total simplicity could bring into proper prominence what is essential. Konsistorialrat Albert Mölk assisted in implementing the new regulations. The reform program aimed to control tightly liturgical practice, significantly limiting the para-liturgical services popular with the folk. It touched everything, from the number of benediction services, devotions, exorcisms, and exposing of the Host, to the numbers of candles on the altar. Among many things, it curtailed

Published in Der aufgeklärte Reformkatholizismus in Österreich, ed. Hersche, 45-102.

6 The author of the Hirtenbrief is said to be Konsistorialrat Michael Bönike. Hollerweger, Die Reform des Gottesdienstes, $286 \mathrm{f}$.

Ibid.

Ibid., 290.

Jungmann, The Mass of the Roman Rite, 1:153. 
processions, targeting, for example, those on Palm Sunday and Good Friday. Parish churches were to eliminate all superfluous devotions, octaves, novenas, Dreissiger, ${ }^{30}$ Golden Sundays, and Rorate. ${ }^{31}$ In his Vorschläge, Mölk denigrated these practices as "arbitrary, monasticallyborn from a mythical source, based on the selfish outward display of piety" and recommended the removal of "at least in the city, such eating-and-drinking parties, secret gatherings, and a hundred other nonsenses." ${ }^{2}$ The imposition of these changes "hit the people most deeply in their feeling of tradition." ${ }^{33}$

In the Hirtenbrief, Colloredo articulated his views on the current state of music in the church. He repeatedly speaks of "abuses," and as a remedy for these problems, he prescribes congregational hymns: "Next to the Bible, good church hymns in the mother tongue are one of the most excellent means of making public worship edifying and conducive to the awakening of religious feelings." He too brings up the old bugbear "theatrical music." He writes: "Soothing, voluptuous church music [...] only attunes the heart to sensual, carnal feelings, and you go to it for pleasure as you go to the theater for enjoyment." ${ }^{34}$ Colloredo made official the use of the hymnal Der heilige Gesang zum Gottesdienste in der römisch-katholischen Kirche, produced by Johann Kohlbrenner in 1777. This hymnal includes a Singmesse (German Mass) and fifty-three German hymns. Two further editions were produced in Salzburg: one in 1781 , with a second printing in 1790 . The latter contained revisions by Michael Haydn. ${ }^{35}$

To bolster his position, Colloredo quotes from St. Jerome: "We should not sing to God, the Lord with the voice, but rather with the heart; not by the art of the throat and the mouth by which we get accustomed to the mellow, doleful tones of tragedy, so that we hear in church nothing but enchanting voices and theatrical songs; rather [we sing] in fear of the Lord, in edification, in the knowledge of the Lord. The servant of Christ must sing so that it is not the voice of the singer but the words of what is sung that is pleasing; so that evil spirit that was in Saul must be driven out of those afflicted with it, and not

Thirty days of Masses for the dead. I thank Fr. Harvey Egan sJ for this information. Hollerweger, Die Reform des Gottesdienstes, 292-293.

Ibid., 293.

Ibid., 289.

Colloredo, "Hirtenbrief," 74-79.

These were mostly simplifications (ornaments deleted, etc.). Pauly, "The Reforms of Church Music under Joseph II," 375. 
enticed into those [persons] who have turned the house of the Lord into a theater in order to please the folk." ${ }^{36}$

Another factor that may have contributed to Colloredo's thinking about the orchestral Mass was his desire to discourage the veneration of saints, at least as he believed it to be practiced by Catholics in Salzburg. He viewed it as cultic, a means by which people tried to appeal to a frightening, unapproachable God. He deprecated it in his Hirtenbrief in part as follows: "people lean on this illusion, or often go there intentionally, as if God could always be unconcerned with our destiny, insensitive to our troubles, indifferent to our desires, and disinclined to hear our supplication; as when because of this, one must earn it through sacrifice and votive offerings, and again turn away from his one-time conceived purposes [Schlüssen], or must send in advance, here his Mother, there this one or that one, or even a whole host of friends, as easily corruptible and mercenary advocates, so as to force from him permission for human desires, which are often directly opposed to his holy wisdom and to Christian love of neighbor, childish and foolish, and surely in the face of sound wisdom become shameful; as if the worship of saints were so very necessary, so very indispensable, the most important symbol of a true Catholic, an essential point of religion, since even the church has determined no more than that the veneration of saints may be useful and praiseworthy: but also only if we consider their examples, according to the spirit and understanding of the church as encouragement to him who as the most complete model of the most grateful love of God and the most active love of neighbor, faithfully and steadfastly follows in the most thankful and joyful obedience to the will of God and the most trust of God's wisest providence as evidenced on earth." He goes on to stress that the saints, even the most blessed Virgin, "when considered against the omnipotent God, are only creatures and immensely lower beings, who can do and desire nothing but to intercede; but if the wishes of men are folly, opposed to the noble love of neighbor and godly wisdom, they will never intercede." ${ }^{37}$

Haydn composed the Missa Sancti Hieronymi in the final year of the abovementioned Salzburger Kongress, the year that the Kohlbrenner Gesangbuch was introduced, and probably in the midst of the introduction of Colloredo's reforms. It was Haydn's third Mass following the accession of the Archbishop on 14 April 1772. The first,

36 Colloredo, "Hirtenbrief," 78. My translation, italics added. The opening words of this passage relate to Ephesians 5:19.

37 Colloredo, "Hirtenbrief," 91-92. My translation, italics in source. 
Missa Sancti Joannis Nepomuceni, was completed on 21 May 1772, about one month after the archbishop arrived in Salzburg, making his influence on its design open to question. The second, Missa Sancti Amandi (26 March 1776), was not written for the cathedral but rather for the Benedictine Abbey of Lambach in Upper Austria. Thus, it is reasonable to conclude that the Missa Sancti Hieronymi represents the first Mass that Haydn composed specifically for the Salzburg cathedral under the new archbishop.

Nevertheless, as mentioned above, the archbishop did not celebrate the first performance of this Mass. Instead, a canon of the cathedral, Prince-Bishop of Chiemsee, presided. ${ }^{3}$ Indeed, several uncertainties surround this Mass. It was intended for a pallium feast but lacked the full instrumentation of the missa solemnis, which required the presence of trumpets and timpani. It has been suggested that Colloredo avoided solemn high Masses, often leaving Festa Pallii to lower prelates. A diary entry by the Abbot of St. Peter on Christmas Day 1784 notes: "The archbishop again failed to celebrate High Mass, and thus there was only one occasion in the entire year at which he celebrated Mass, O Tempora!" ${ }_{9} 9$ In any event, after this Mass, Haydn wrote only one more missa solemnis for the Salzburg cathedral (Missa in honorem Sancti Ruperti, 1782). This suggests that Colloredo's attempts to modernize musical practice in Salzburg did have a dampening effect on this significant aspect of the composer's productivity..$^{40}$

Despite Colloredo's failure to attend the first performance of the Missa Sancti Hieronymi, it has been proposed that he did commission it for the occasion of his name day. Indeed, to some extent, this explanation provides a logical genesis of the Missa. Editor Armin Kircher suggests that Colloredo probably commissioned the Mass and followed its progress with interest, noting that the archbishop

\section{Arenas, "Johann Michael Haydn," 158.}

Ibid., 215.

These reforms applied chiefly to parish churches, apparently requiring no changes in cathedral or monastic churches (Stifts- und Klosterkirchen.) Colloredo, "Hirtenbrief," 75. Nevertheless, evidence suggests that Colloredo's reforms were not popular and that his efforts to have worshippers sing vernacular hymns did not succeed. Parishioners refused to sing the German hymns, and those who could easily cross the border, attended services in Bavaria, where instrumental music was still permitted in Mass. Eisen, "Salzburg under Church Rule," 180. Colloredo also restored the choral gradual of the Mass, which had been replaced by an instrumental piece. In response to this reform, Haydn composed over 100 graduals and offertories in the 1780 s. 
attended a rehearsal of the first two movements. Further, he references Colloredo's fondness for Harmoniemusik (chamber music scored for two oboes, two bassoons, and two horns). Based on this secular musical preference, Kircher postulates that the wind-band scoring of the Missa could have resulted from a direction by the archbishop..$^{41}$ These conclusions, however, must be considered in light of the many uncertainties surrounding the work.

Records of Haydn's later thoughts or plans for the Mass raise additional questions about its instrumentation. In a letter of 21 March 1786 to the Viennese publishing firm Artaria, Leopold Mozart wrote that Haydn wanted to modify the scoring, "with the accompaniment of violins and other [instruments]." ${ }^{42}$ Mozart's comment does not make clear whether by modify [abändern] he meant the addition of violins or substitution of violins for existing winds. There is no evidence that Haydn ever carried out this idea. From Haydn pupil Sigismund Ritter von Neukomm (1778-1858) we learn that Haydn contemplated an even more radical score alteration. In a catalog of his own works, Neukomm quotes from a letter of Haydn, stating that he intended to augment the score with flutes, horn, trumpets, and timpani. Neukomm also reports that Haydn mentioned adding the "recently introduced instruments found everywhere, such as clarinets and flutes." He described the Mass as "too paltry" [armselig] for Vienna. These later thoughts about the enhancement or improvement of the Missa suggest that Haydn was not satisfied with the work as first created. If, as has been proposed, it derived from directions given by the archbishop, perhaps he was never happy with the effect. According to Neukomm, Haydn started to revise the score, probably adding some of these instruments, but left it unfinished. ${ }^{43}$

How then does Michael Haydn's music measure up as a composition fit for or reflective of St. Jerome? We know that Haydn was a deeply religious man. His early biographers called him "a Catholic with all his soul" and said of his sacred music: "Every place in his church compositions is an open avowal of his faith [...] In all his compositions breathes the spirit of the most heartfelt and solemn praise of God [...] He did not try at all to attract attention to himself with his church compositions in the court chapels, cathedrals, etc.; he was content to unfold the majesty of God through the magic of harmony before 
devotion-filled hearts, where it might also beat." ${ }^{34}$ Moreover, Haydn was careful to set liturgical texts that would express the mood and meaning of the words precisely. ${ }^{45}$

Contemporaries deemed Haydn's sacred music as deeply inspiring and uplifting. The main reason for this is that his religious compositions uniquely fit the purpose. The Salzburg Abbot Dominikus stated this precisely in a diary entry: "He was 43 years in local service and was especially esteemed by the church music he composed astonishingly much in the real church-music style." ${ }^{36}$ That is, his music expressed "the real church music style" more truly than the church music of other masters. At this time, the "real church music style" consisted above all of good contrapuntal writing. It may be remembered that the supreme musical master, Wolfgang Amadeus Mozart, called M. Haydn a "superlative master of counterpoint" (see note 9).

Based on what we know about Haydn's spirit and character, we must conclude that his music does indeed fulfill Jerome's prescription: it does "sing from the heart, in the knowledge of the Lord." It would not be a stretch to think that as he composed this Mass, Haydn had in mind St. Jerome himself. Possibly he associated the spare wind-band scoring with the ascetic character of the saint. True, Haydn wrote the Missa Sancti Hieronymi as the dutiful servant of his employer. Given the composer's understanding of the deeper purpose of sacred music as a statement of faith, however, surely he meant this Mass, perhaps above all, as a tribute to the fourth-century saint.

46 Jancik, Johann Michael Haydn, 276. Quoted in Robbins Landon, Haydn, vol. 5, 347. 


\section{BIBLIOGRAPHY}

Arenas, Erick. "Johann Michael Haydn and the Orchestral Solemn Mass in Eighteenth-Century Vienna and Salzburg." PhD dissertation, Stanford University, 2013.

Burney, Charles. The Present State of Music in Germany, the Netherlands, and United Provinces. London, 1775. Reprint New York: Broude Brothers, 1969.

Clive, Peter. Mozart and His Circle: A Biographical Dictionary. New Haven: Yale University Press, 1993.

Colloredo, Hieronymus Joseph. "Hirtenbrief auf die am iten Herbstm. dieses Jahrs, nach zurückgelegten zwölften Jahrhundert, eintretende Jubelfeyer Salzburgs." In Der aufgeklärte Reformkatholizismus in Österreich, edited by Peter Hersche, 45-102. Bern: Verlag Herbert Lang, 1976.

Eisen, Cliff. "Salzburg under Church Rule." In The Classical Era, edited by Neal Zaslaw, 166-187. Englewood Cliffs, NJ: Prentice Hall, 1989.

Glöggl, Franz Xaver. Kirchenmusik-Ordnung: Erklärendes Handbuch des musikalischen Gottesdienstes, für Kapellmeister, Regenschori, Sänger und Tonkünstler. Vienna: J. B. Wallishauser, 1828.

Hayburn, Robert F. Papal Legislation on Sacred Music: 95 AD to 1977 AD. Collegeville, mN: The Liturgical Press, 1979. Reprint Harrison, NY, n. d.

Haydn, Johann Michael. Missa Sancti Hieronymi. Edited by Armin Kircher. Stuttgart: Carus-Verlag, 2006.

Hollerweger, Hans. Die Reform des Gottesdienstes zur Zeit des Josephinismus in Österreich. Regensburg: Verlag Friedrich Pustet, 1976.

Jancik, Hans. Johann Michael Haydn: Ein vergessener Meister. Zurich: Amalthea Verlag, 1952.

Jungmann, Joseph A. sJ. The Mass of the Roman Rite: Its Origins and Development. Tr. Francis A. Brunner CssR, 2 vols. Allen, TX: Christian Classics, 1986.

Mac Intyre, Bruce C. The Viennese Concerted Mass of the Early Classic Period. Ann Arbor, MI: Umi Research Press, 1986.

Mozart: Briefe und Aufzeichnungen, Gesamtausgabe. 7 vols. Edited by Wilhelm A. Bauer and Otto Erich Deutsch. Basel: Bärenreiter, 1962-1975.

Pauly, Reinhard G. “The Reforms of Church Music under Joseph II." Musical Quarterly 43 (1957): 372-382. 
Reformation, Emigration: Protestanten in Salzburg, Ausstellung Oktober 1981, Schloß Goldegg-Pongau, Land Salzburg. Edited by Friederike Zaisberger. Salzburg: Salzburger Landesregierung, 1981.

Robbins Landon, H. C. Haydn: Chronicle and Works, vol. 5, Haydn: The Late Years, 1801-1809. London: Thames and Hudson, 1977. Schuler, Heinz. "Fürsterzbischof Hieronymus von Colloredo:

Herkunft und Ahnenerbe." Mitteilungen der Internationalen Stiftung Mozarteum 34:1-4 (1986): 1-30.

Sherman, Charles H., and T. Donley Thomas. Johann Michael

Haydn (1737-1806): A Chronological Thematic Catalogue of His Works. Stuyvesant, NY: Pendragon Press, 1993.

— . "The Masses of Johann Michael Haydn: A Critical Survey of Sources." PhD dissertation, University of Michigan, 1967.

Stelton, Leo F. Dictionary of Ecclesiastical Latin. Peabody, MA: Hendrickson Publishers, 1995.

Zaslaw, Neal. Mozart's Symphonies: Context, Performance Practice, Reception. Oxford: Clarendon Press, 1989. 


\section{ABSTRACT}

Johann Michael Haydn (1737-1806), court musician to the princearchbishop of Salzburg, composed the Missa Sancti Hieronymi in 1777 , apparently intended to mark the name-day of his employer: 30 September, the feast-day of St. Jerome. Because of its wind-band scoring, this Mass is unique, not only among Haydn's Masses, but also in the Mass repertoire of Salzburg, and apparently in that of all late eighteenth-century Austria. The present article discusses the environment in which Haydn functioned and its effect on the practice of church music in Salzburg and generally in Catholic Austria. Haydn's employer, Archbishop Colloredo, was a proponent of Enlightenment thinking. He expressed in his Hirtenbrief of 1782 ideas opposed to the kind of sacred music then prevalent in Austria, in particular, the orchestral Mass. Reflective of the new Gottesdienstordnung promulgated by Emperor Joseph II, the proposed changes include the introduction of congregational hymns in the vernacular and severe reduction in numbers of liturgies and the amount of music allowed in them. Colloredo finds support for his ideas in the writings of St. Jerome and other church fathers. Given Haydn's strong Catholic faith and dedication as a composer of sacred music, the article suggests that although he wrote the Missa as a dutiful servant of his employer, he meant it above all as a tribute to St. Jerome.

KEYWORDS: Johann Michael Haydn, Archbishop Colloredo, Enlightenment, Emperor Joseph II, Salzburg 


\section{MISSA SANCTI HIERONYMI JOHANNA MICHAELA HAYDNA: NENAVADEN POKLON SVETEMU HIERONIMU IZ OSEMNAJSTEGA STOLETJA}

\section{IZVLEČEK}

Johann Michael Haydn (1737-1806), dvorni glasbenik salzburškega knezonadškofa, je leta 1777 zložil mašo Missa Sancti Hieronymi, najverjetneje za god svojega delodajalca, 3o. septembra, na praznik svetega Hieronima. Maša je zaradi pihal edinstvena, ne zgolj med Haydnovimi mašami, temveč tudi v mašnem repertoarju Salzburga in bržkone vse Avstrije poznega osemnajstega stoletja. Članek obravnava okolje, v katerem je Haydn deloval, in njegov vpliv na prakso cerkvene glasbe v Salzburgu in v katoliški Avstriji nasploh. Haydnov delodajalec, nadškof Colloredo, je bil pristaš razsvetljenskega razmišljanja. V svojem pastirskem pismu iz leta 1782 je izrazil zamisli, ki nasprotujejo sakralni glasbi, kakršna je takrat prevladovala v Avstriji, zlasti orkestralni maši. Predlagane spremembe odražajo novo Gottesdienstordnung, ki jo je razglasil cesar Jožef II., in vključujejo uvedbo občestvenih hvalnic v ljudskem jeziku ter izrazito zmanjšanje števila bogoslužij in dovoljene količine glasbe $\mathrm{v}$ njih. Colloredo je podporo za svoje ideje našel v spisih svetega Hieronima in drugih cerkvenih očetov. Glede na Haydnovo močno katoliško vero in na predanost, ki jo je kazal kot skladatelj sakralne glasbe, članek ugotavlja, da je mašo resda napisal kot vesten uslužbenec svojega delodajalca, da pa jo je razumel predvsem kot poklon svetemu Hieronimu.

KLJUČNE BESEDE: Johann Michael Haydn, nadškof Colloredo, razsvetljenstvo, cesar Jožef II., Salzburg 